\title{
Urban politics in Brazil and the US: state, economic actors and local development scenarios ${ }^{*}$
}

\author{
Política urbana no Brasil e Estados Unidos: Estado, \\ atores econômicos e cenários de desenvolvimento local
}

Nelson Rojas de Carvalho

\begin{abstract}
This paper analyses different patterns of articulation between market and state in subnational units in Brazil and the US, and forecasts scenarios that are more or less prone to enhancing development policies locally. Based on a state-centered perspective, the paper argues that institutional grammars such as clientelism and corporatism produce disincentives to the organization and civil engagement of economic actors in Brazil, in the subnational level. The paper stresses that the organizational atrophy of economic actors in Brazil, at the local level, limits the use of urban theories inspired by the North American political economy, such as urban regime and growth machine theories.
\end{abstract}

Keywords: state; economy; local development; urban theory.

\section{Resumo}

0 presente artigo explora modalidades diversas de articulação entre mercado e estado em unidades subnacionais no Brasil e nos EUA e infere daí os cenários mais ou menos favoráveis a políticas de desenvolvimento em âmbito local. Partindo de enfoque centrado no Estado, o artigo chama a atenção para os desincentivos à organização e ao engajamento cívico dos atores econômicos no Brasil, no plano subnacional, como efeito de determinadas gramáticas institucionais, como o clientelismo e o corporativismo. Chama a atenção para o fato de a atrofia organizacional dos atores econômicos no Brasil, em âmbito local, limitar a aplicação das teorias urbanas inspiradas pela economia política norte-americana, como a teoria dos regimes urbanos e a teoria das máquinas de crescimento.

Palavras-chave: Estado; economia; desenvolvimento local; teoria urbana. 


\section{Introduction}

In the history of studies in the US on urban politics and community power, scholars from a wide variety of theoretical backgrounds have assigned a central role to economic actors within different local hierarchies and ruling coalitions. From the earliest elitist/pluralist debates (Dahl, 1961; Hunter, 1953; Polsby, 1963) on the nature of power within the community to the later and more influential research path framed by a political economy perspective (Molotoch, 1976; Peterson, 1981; Stone, 1989), the role of business has been not just under permanent scrutiny, but also acknowledged to play a major, if not determining, part in cities' and regions' fortunes. It would be no exaggeration to say that elitist, neo-pluralist and political economy theories on cities and regions have been built on two related assumptions: a) business has been playing a major role in the fates of US cities; b) a central issue of the research agenda is to define and measure the nature and extent of the power of business within communities.

Whereas the first generation of research into community power was confined within the borders of the US, studies inspired by the political economy perspective - particularly urban regime and growth machine theories - have successfully managed to cross the Atlantic, setting the framework for what can be regarded as the first wave of European studies on local urban power and development. It is worth noting that the successful, though not always smooth, transfer of US urban theories outside the country's borders has extended, in recent years, into Latin American political science and urban studies departments, unshackling these fields from their outdated Marxist-structuralist approaches.

Similarly to the path followed in Europe, the attention given by Latin America to more recent US theories in the field of urban politics has much to do with transformations to the state brought about by globalization, with profound changes being observed in the relation of mutuality between cities and regions (Taylor, 1995) on one hand, and the state on a national level on the other. State rescaling (Brenner, 2004) in Latin America and elsewhere generally represents a process whereby subnational units such as cities and regions have been endowed with increasing structural significance and autonomy within each territorial state's administrative hierarchy.

Globalization processes have sparked a broad range of transformations in the structure of the Fordist-Keynesian state that has been in operation since the 1930s (Brenner, 2004), and such changes have reached Latin American's regions and nation states with varying intensity. State rescaling processes that have increased cities' and regions' autonomy across the continent have varied significantly as a result of their different institutional backgrounds and due to the specific relations of mutuality between cities and nation states.

Regarding the impact of the globalization process on the structure of the Brazilian state, it is worth emphasizing that global pressures toward state rescaling have not only been aligned with ongoing internal state decentralization processes in the country, but have also reinforced them. ${ }^{1}$ The democratization and neoliberal reforms that were set in motion in Brazil in the 1980s 
led to the withdrawal of state intervention in important economic sectors and in delivering significant welfare provisions on one hand, and to a decentralization process that has empowered subnational units on the other, particularly municipalities, in terms of both fiscal resources and new constitutional attributions. In summary, as a result of the joint effect of global and internal processes, cities and city regions in Brazil have been gaining ground as autonomous actors, becoming the stage for new capital flows.

It is within this context of profound change concerning the relative position of cities and the state at a national level in Brazil, with the former gaining increasing autonomy, that a shift in the academic agenda in this country has also been observed. From an almost exclusive concern for national governance structures, it has begun to focus on modes of governance at the subnational levels of cities and regions. Due to these changes, it is not difficult to envisage that analyses of different modes of governance at a subnational level will be at the center of the research agenda in Brazil over the next few years. It goes without saying that the fulfillment of this new agenda implies a close dialog with second generation US literature on city politics, especially in terms of growth machine and urban regime theories, as well as an evaluation of the limits and possibilities provided by these.

The purpose of this paper is to take the first step in this direction, analyzing the role of economic actors in Brazilian municipalities and city regions from a comparative perspective. It will be shown that, despite some signs of civic life in Brazilian municipalities, embodied by the participatory budget experience, economic actors are far from playing an active role in local urban development in the same way as this can be observed in US cities. If this is true, the use of urban regime and growth machine theories will require essential modifications when applied to the Brazilian context.

In this paper, both neo-institutionalist and state-centered approaches are used to explain the underdevelopment of the organization of business in Brazil and the near absence of civic participation by economic actors at a local level. It is argued that the two main institutional frameworks that have underpinned local governments along the country's history - state corporatism and clientelism/patrimonialism - are at the root of strong incentives encouraging economic actors not to organize or act collectively: a) while prioritizing the production of distributive goods at the expense of regulatory and redistributive politics, patrimonialism and clientelism encourage business to foster individual, short-term, rent-seeking strategies that inhibit developmental strategies; and b) while aiming, at the same time, to organize and accommodate the main social actors, such as business and trade unions, the top-down hierarchical structure of state corporatism leads to short-lived organizations being put in place. In the absence of an ongoing stimulus from above, the corporatist structure is at risk of falling apart and being replaced by a myriad of parochial and conflicting organizations. Therefore, it is argued that the nature of the Brazilian state has thwarted the autonomous organization of business at a local level from different and opposing directions; this, in turn, makes cities and city regions in Brazil less likely to pursue the type of developmental policies described by the political economy literature 
in its analysis of US cities. State structures at a local level in Brazil are, therefore, a hindrance to the development of collective action on the part of economic actors, and the mainly distributive and rarely productive nature of the country's federalism is an additional institutional obstacle preventing cities from setting up growth machines and pursuing developmental policies. As local governments in the country are now in charge of developing the important social programs that central government has transferred to municipalities over the last few decades - in education, health and social care -, mayors and city council members have few opportunities or resources and little leeway to place economic and developmental issues firmly on the political agenda.

This paper is divided into three sections. The first highlights the main factors that, in the view of current scholarship, account for the weak organization of business in Brazil, alongside some major and broader theories on the rationale behind the structure of the country's state. The second analyzes statecorporatist and clientelist modes of governance respectively in Brazil's steel capital, the city of Volta Redonda, and in the Metropolitan Region of Rio de Janeiro, where business has not formed an independent organized sector to press for the implementation of developmental policies. This section also discusses a central trait of federalism in Brazil: local government is expected to carry out the bulk of redistributive policies transferred by central government to municipalities (Arretche, 2012). This results in an institutional framework in which there is little room or incentive left for political and economic actors to push forward developmental policies. In the final section, based on the marginal participation of economic actors and the redistributive nature of Brazilian federalism, an evaluation is provided of the extent to which theories of urban politics based on political economy perspectives can shed light on the reality of Brazilian cities and city regions. It is concluded that, whereas the rescaling of the state on a national level, sparked by globalization, has pressed for local autonomy and local development policy, Brazilian state structures and the nature of intergovernmental relations in the country have refracted these broad inputs in the most diversified ways, aligned with the path dependency of local institutions and the specific division of labor between the market and the state in each municipality.

\section{Business politics and the Brazilian state}

As for the two main traits of the literature regarding the relation between market and state in Brazil that focus on the place of business politics in the country, we must stress, first of all, that this literature is limited in terms of the amount of research work undertaken and also in its scope, as it focuses exclusively on the national scale. That said, the purpose of this paper is to pave the way for a new line of research and explore a subject that has, until now, received very little attention - namely, the nature of business politics and patterns in the articulation between the state and the market at a subnational level in Brazil. It is worth noting that, moving from a national to a subnational level of analysis, the very nature 
of the question to be researched is bound to change. Whereas at a national level inquiries relating to business associations in Brazil and elsewhere are usually related to countries' macro-economic and democratic performance, this inquiry into business associations at a subnational level brings about a double challenge: both normative and theoretical. On the one hand, a comparative analysis with US cities must be performed in order to assess the feasibility of resorting to urban politics theories following political economy assumptions, as expressed in urban regime and growth machine theories, for the analysis of Brazilian cities. On the other hand, it should be identified to what extent cities and city regions in Brazil can host developmental politics and set out projects with a view to attracting capital and enterprise, based on the traditional premise that these are the final links in a redistributive chain that is spearheaded by the national government.

With these caveats in mind, the conclusion of Schneider's (2004) impressive comparative research into the organization of business in Latin America can be discussed. According to the author, a striking feature of business organization in Brazil throughout the twentieth century was its feebleness: contrary to patterns observed for countries such as Mexico, Chile and Colombia, Brazil does not have a history of lasting economy-wide peak association. One example identified in Schneider's research seems to provide a sufficient indication of the impressive weakness of Brazilian business organizations, which is much more pronounced than that of its neighboring countries. Despite the fact that Brazil and Colombia are important coffee producers and exporters, the level of organization in this sector for each country differs dramatically. In Colombia, "the political power of the coffee elite and their association matched their economic clout. Federacafe was influential in a wide range of economic policies and its head was viewed as the second most powerful man after the president" (Schneider, op. cit., pp. 3-4). In Brazil, despite the country's position as the world's largest coffee producer at the time, the political and organizational position of its coffee sector was completely marginal. In Schneider's words, "any general book on Colombian politics or development in the second half of the twentieth century devotes substantial attention to Federacafe; similar books on Brazil make no mention of a national organization of coffee growers (Schneider, op. cit., p. 4)". It is worth stressing here that the void of voluntary and encompassing business organizations in Brazil is not a trait limited to the coffee economic cycle or production sector. This has been a lingering characteristic of business politics and organization in the country. Indeed, the resistance of capitalists and businessmen in Brazil to engage in collective action has been enduring. There is no better example than the fact that, since the first few decades of the twentieth century, only two very ephemeral economy-wide, voluntary, and encompassing associations have been established in the country: the Brazilian Union of Businessmen (UBE) and the Institute for the Study of Industrial Development (IEDI).

Although it is true that in the last few decades Brazil has fallen behind all of its neighboring countries in terms of its level of business organization, in the 1940s and 1950s the situation in the country was quite different as far as the relationship between state and society was concerned. As it is widely known, 
during this period Getúlio Vargas sparked a huge process of state-led industrialization and economic development, creating the path that would ultimately transform the country from a crop producer and exporter into a regional industrial powerhouse. It is worth stressing that, alongside the deep economic changes that were set in motion, there was an equally significant overhaul of the state's organization and structure. First, Vargas' revolution involved a ban on liberal-democratic institutions: congress was dissolved, elections were cancelled and a new constitution endowed with fascist elements was decreed. It also involved tearing down the existing liberal-democratic structure and replacing it with corporatist organizations sponsored and backed by the state. Brazil became a model of state corporatism, a variety of capitalism whereby state authority and force establish and support a system of socio-economic organization and representation "in which the constituent units are organized into a limited number of singular, compulsory, noncompetitive, hierarchically ordered and functionally differentiated categories (Schmitter, 1974, p. 93)". In state corporatism, as emphasized by Schmitter, "corporations were created by and kept as auxiliary dependent organs of the state which founded its legitimacy and effective functioning on other bases" (op. cit, pp. 102-103).

Therefore, it was for no other reason that the lack of business organization in Brazil experienced a totally different reality in the 1930s and 1940s, though deceptive and short-lived, when compulsory business organizations were artificially created and kept alive by the state. As highlighted by Schneider (2004), "Vargas' governments gave business strong incentives to organize. These incentives included compulsory dues and membership, delegated public functions like the provision of worker training and other social services, and extensive representation in industrial federations" (p. 105). It is worth stressing that, besides compulsory membership dues, Vargas created a one per cent tax payroll to finance work training, amassing a fund of millions administered exclusively by corporatist business associations, in this way providing an additional incentive for business to organize. As a result of these stimuli, industrial associations popped up throughout the country in a short period of time. The Federation of Industries of the State of São Paulo (Fiesp) - by far the strongest organization - channeled the interests of São Paulo's industries, which were responsible for the largest share of Brazilian industrial output. "The result by the end of the period was amazingly strong industry associations, beyond the dreams of the São Paulo industrialists who first created Ciesp in 1928. Ciesp became Fiesp to conform to the 1931 decree creating official sindicatos (sectoral associations) and encompassing federations of these sectoral sindicatos. (...) By 1941, membership and revenues had doubled. According to Fiesp estimates, its member firms in 1940 accounted for two thirds of Paulista industry (in terms of capital and number of workers). National-level organizing also proceeded quickly. In 1933 state federations from São Paulo, Rio de Janeiro, and Rio Grande do Sul created the Confederação Industrial do Brasil, renamed the Confederação Nacional da Indústria (CNI) in 1938" (p. 99).

Business organizations in Brazil enjoyed their heyday in the 1930s and 1940s thanks 
to the corporatist laws that set up compulsory dues and membership, but these would turn out to be ephemeral and short-lived. Apart from the well-known shortcomings stemming from hierarchical organizations, such as the high cost of enforcement and the asymmetrical flow of information, business associations artificially created by law soon began to misrepresent the actual economic forces within the country. As noted by Schnneider (2004), the rigidity of state corporatist laws caused an ever-growing chasm in the representation between industries and business organizations: "[...] by the 1990s, traditional sectors of industry accounted for $16 \%$ of value added in São Paulo, but had $44 \%$ of votes in Fiesp" (p. 95). On a national level, the CNI led to less industrialized states being disproportionally overrepresented. As properly stressed by Schneider, "As these associations ossified, they not only ceased to represent big business but also filled the organization space and thereby impeded efforts by big business to find alternative channels for collective action and representation (...)" (p. 97). Therefore, if the history of business organization in the country were to be traced, this would demonstrably amount to weak organizations that were artificially and temporarily boosted by Brazil's experience of state corporatism.

\section{The Brazilian state beyond corporatism: competing narratives and the challenge of subnational realities}

It is worth stressing here that Schneider (2004) identifies the organization of business with a classical collective action equation solved by selective incentives provided by the state, in a clear commitment to a statecentered analysis: "My argument is [...] when it organizes, the private sector is essentially a reactor to government actions" (p. 11). State actors were, therefore, not only the cause of corporatist associations created by decree, but also of voluntary and encompassing associations created by means of selective benefits such as representation in policy arenas or authority over public functions or funds. Though committed to reintroducing the state, Schneider's analysis avoids any structural narrative or even corporatist analyses, which in his view would prevent any explanation of variations in business associations. According to the author, although organizations are not described as immutable in corporatism as they are depicted within analyses of civil society, change would be still slow and constrained. Even if most corporatist analyses also reintroduced the state, this would emerge as "a structure and monolith". In order to capture variations in business organization, Schneider makes a strong case for an actor-centered research approach, aimed at analyzing the micro-motives of state actors.

At this point, it is necessary to highlight what seems to be an important shortcoming in Schneider's analysis of business organization, which turns out to be a hindrance to further steps in understanding the extent to which economic actors organize at a subnational level. It is worth discussing three considerations in this regard:

1) Even though Schneider criticizes the narrowness of a straight collective action approach to business organization for neglecting to consider the context and the 
state, he does not provide a minimum definition for state structures in Latin America.

2) It is not true that structural state approaches do not account for variations: not only does the traditional literature on policy arenas (Lowi, 1972) and polity networks (Rhodes, 1997) imply different patterns of state interaction with society, but these narratives also depict the state as a non-coherent system resulting from an adaptive process of institutional change, where traditional structures fit into and coexist with modern ones (Nunes, 1997).

3) Mapping different institutional or state structures that exist side by side, sometimes in a disharmonious way, may be a fundamental and necessary step as one moves down from the perspective of the nation state towards local realities. This demand was envisaged and met by Locke (1995) in his research on the causes underlying differing regional patterns of economic development in Italy. Contrary to the current view of a coherent and homogeneous institutional nation state, he makes his case and follows an alternative viewpoint, according to which "national political economies are not coherent systems but rather incoherent composites of diverse subnational patterns that coexist (often uneasily) within the same territory" (p. 3).

Considering these caveats while following a state-centered path to explaining the different patterns of business organization in Brazil at a subnational level, an account of the Brazilian state and institutional matrix that can cope with the country's institutional diversity is used. A perspective is taken in which the path of state building and modernization in Brazil did not translate into a linear and gradual suppression of traditional institutions, or the convergence towards a homogenous and modern institutional landscape. On the contrary, this evolved and unfolded through the juxtaposition of different institutional frameworks, whereby traditional routines were embedded into more modern practices.

In line with this perspective, Nunes' (1997) account of Brazilian state building stands out, according to which four institutional grammars underpin the pattern of articulation between state and society in Brazil: clientelism, corporatism, procedural universalism and bureaucratic insularity. In Brazil, formal institutions function according to a combination of one or more of these grammars that varies along different historical periods. For the purposes of this paper, it is worth stressing that, whereas clientelism amounts to an institutional pattern that frames traditional societies and relations, procedural universalism underlies modern, marketoriented societies and relations. The former is based on a pattern of personal and asymmetric relations where all goods or actions that are exchanged are embedded in a broader setting of lasting interpersonal bonds and duties, along with expectations of future payoffs. However, the latter is related to impersonal patterns of relations where goods and actions are exchanged according to procedures that apply without consideration for the characteristics of the parties involved. In this way, procedural universalism turns out to be an institutional basis for modern capitalism and a necessary, though not the sole, condition for liberaldemocratic orders.

Regarding the two other institutional frameworks - corporatism and bureaucratic 
insularity -, these lie somewhere between the extreme institutional formulae that distinguish traditional and modern societies; namely, clientelism and procedural universalism respectively. Even though bureaucratic insularity implies a process through which the state's technical sectors are protected from the pressures that stem from political parties and pressure groups, these are in no way free from clientelist inroads. Corporatism, on the other hand, sits far from procedural universalism as it seeks policies of accommodation by shrinking the number of competing groups. In this sense, as Nunes recalls, both clientelism and corporatism could be said to share common ground, as they are both mechanisms that prevent social conflicts from sparking.

It is assumed along with Nunes that the Brazilian state is characterized by a range of institutional grammars, and a further step is taken by establishing the hypothesis that a different landscape is faced when moving down to local government. At a local level, since city limits exist (Peterson, 1981), the complexity of the state is lower and institutional patterns that are less hybrid than those observed at a national level should be expected.

That said, a second hypothesis is proposed: at a subnational level, a pattern of institutional heterogeneity that is regional in scope is expected. In other words, city and city regions should vary according to different institutional frameworks, with different patterns of articulation between the state and society. Even though this is not the purpose of this research, an open question exists regarding how the four institutional grammars identified at a national level unfold within cities and city regions in Brazil, whether there is a predominant institutional framework at this level and whether the four grammars are spread evenly or unevenly throughout the territory.

For the purpose of this exploratory research, the following sections provide an analysis of how two of these institutional grammars - corporatism and clientelism unfolded within two Brazilian local realities, the city of Volta Redonda, the Brazilian steel capital, and the Rio de Janeiro metropolitan region. It is verified that both corporatism and clientelism hindered not just business organization but also the pursuit of developmental politics in these regions. Analyzing these cases, a parallel is drawn between Brazilian local realities and the cities of Pittsburgh and Chicago, where a variety of corporatism and clientelism (political machine) has not thwarted the pursuit of growth and developmental politics.

\section{State corporatism in Volta Redonda: from rigid organizations to loose and conflicting pluralism and challenges to economic growth}

Once the steel capital of the US, Pittsburgh saw its fortunes disintegrate with the collapse of the American Steel Industry. As Barbara Ferman (1996) recalls, if the cyclical nature of the manufacturing sector inevitably brings about job losses as a long-term trend, Pittsburgh experienced its real crunch between 1979 and 1988 , when 110,000 jobs were lost, 
representing a $44 \%$ decline in manufacturing employment. As it is well known, the private and public sectors joined in a pattern of cooperation that goes back to the 1940 s, steering the city towards a new service-based, high-tech economy. Even if the results of this were positive, it did not fully compensate for the losses resulting from the crisis in the manufacturing sector. As Fitzgerald (1988) states, "the number of jobs created in the service sector has not been sufficient to replace the jobs lost in manufacturing. Between 1979 and 1986, the Pittsburgh PMSA lost 97,457 jobs in manufacturing and gained 33,304 jobs in the service sector. Even if the service sector could absorb all those displaced from manufacturing, incomes would be below those in manufacturing. Not only do jobs pay less in the polarized service sector, but they offer fewer fringe benefits and are more likely to be part time than jobs in the manufacturing sector (p. 246)". In addition to evaluating the achievements of Pittsburgh's economic conversion policies, it is worth pointing out that the city, through a consensual pattern of policy-making since the 1940s, has been fostering growth policies with different targets: downtown regeneration (renaissance 1 ), downtown and neighborhood development (renaissance 2), and ways to put a high-tech economy in place (strategy 21).

Once the steel capital of Brazil, the city of Volta Redonda shares some characteristics with the US steel capital, to the extent that for many decades it was named the "Brazilian Pittsburgh". It is worth pointing out the historical importance of Volta Redonda: the city was chosen by President Getúlio Vargas in the 1940s to implement one of his most important and strategic projects for the nation on its new path towards industrialization: the construction of the biggest steel company in the country and the continent, the National Steel Company (CSN). ${ }^{2}$

As a state-owned company embedded in the state corporatism championed by Vargas, CSN played a central role not only in planning, but also in managing the territory of the newly founded city. Sparsely populated before the installation of its steel mill, Volta Redonda would later become the archetype of the Brazilian company town. Housing, schools, hospitals, movie theaters and clubs were built along with the steel mill, providing the necessary urban facilities for this industry to operate. Later, CSN took on full responsibility for both providing and maintaining the main urban services, such as water supply, sewerage, street lighting, the construction and conservation of housing and telephone communications. It was only in the 1960s that the responsibility for some of these services was transferred to the City Hall. By this time, the population of the city had reached 100,000 , with 13,000 workers on the payroll of the steel mill. To a large extent, it can be argued that the city of Volta Redonda is an offspring of the CSN.

After it was built in the 1940s, the company and the city of Volta Redonda experienced four decades of steady growth. In contrast to the US steel companies, CSN underwent two decades of crisis in the 1980 s and 1990s, resulting in a complete overhaul in its internal managerial procedures and ultimately leading to the company's privatization in 1992. It is worth stressing that 8,000 workers were laid off during this privatization process, and in 2002, 500 
qualified employees, along with the company's administrative headquarters, ${ }^{3}$ were relocated to the city of São Paulo. This caused the city to be hit by a loss of 32,000 indirect jobs, with spillover effects to the service and retail sectors. According to Dulci (2008), between 1996 and 2006, the percentage of workers in the manufacturing sector in Volta Redonda fell from $37 \%$ to $20.6 \%$, along with a $20 \%$ loss in workers' income. It goes without saying that the relocation of the company's headquarters had a deeper effect than a simple loss in the number of jobs: it led to the loosening of CSN's historical attachment to the location, or in other words, its commitment to the city.
As has happened in other steel company towns, in the last few decades Volta Redonda's manufacturing sector has steadily been losing ground to the service sector. Nowadays, services not only account for the largest percentage of jobs, but also for the largest share of added value created in the city. As shown in Table 1, even after the initial layoffs brought about by the company's privatization, the manufacturing sector's role in job creation continued to shrink. Whereas in 1996 it accounted for $37 \%$ of jobs in the city, by 2005 this percentage had shrunk to $17 \%$. Meanwhile, the service sector went from representing $28 \%$ to $40 \%$ of the city's jobs.

Table 1 - Volta Redonda 1996/2005

job evolution according to economic activity/sector

\begin{tabular}{l|c|c|c|c|c|c|c|c|c|c}
\hline & $\begin{array}{c}1996 \\
\%\end{array}$ & $\begin{array}{c}1997 \\
\%\end{array}$ & $\begin{array}{c}1998 \\
\%\end{array}$ & $\begin{array}{c}1999 \\
\%\end{array}$ & $\begin{array}{c}2000 \\
\%\end{array}$ & $\begin{array}{c}2001 \\
\%\end{array}$ & $\begin{array}{c}2002 \\
\%\end{array}$ & $\begin{array}{c}2003 \\
\%\end{array}$ & $\begin{array}{c}2004 \\
\%\end{array}$ & $\begin{array}{c}2005 \\
\%\end{array}$ \\
\hline Manufacturing & 37 & 30 & 29 & 26 & 23 & 21 & 20 & 19 & 18 & 17 \\
Construction of public facilities & 1 & 2 & 2 & 3 & 2 & 2 & 2 & 2 & 2 & 2 \\
Construction & 6 & 6 & 8 & 7 & 10 & 8 & 10 & 9 & 9 & 9 \\
Retail & 15 & 18 & 18 & 19 & 19 & 20 & 21 & 22 & 24 & 23 \\
Services & 28 & 29 & 30 & 33 & 36 & 38 & 37 & 38 & 38 & 40 \\
Civil Service & 13 & 15 & 13 & 12 & 10 & 11 & 10 & 10 & 10 & 9 \\
\hline
\end{tabular}

Source: Estevez (2012). 


\section{Graphic 1 - Volta Redonda GDP \%}

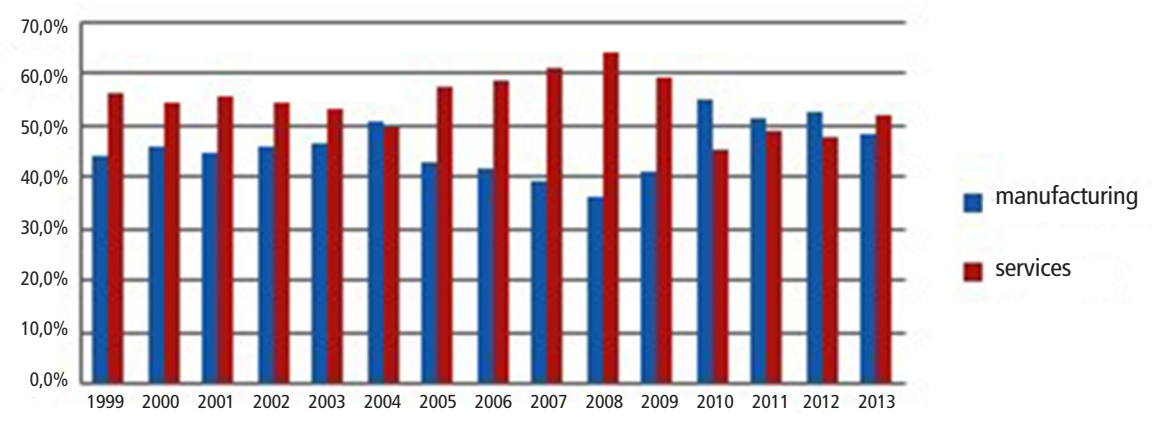

Source: IBGE.

As for the participation of the service sector in local economic output and GDP, it is worth pointing out that these activities have outperformed manufacturing results for all but a few years, as shown in the Graphic 1. It is noteworthy that even during Brazil's commodity boom cycle between 2002 and 2012, manufacturing production did not overtake or even match service output in the city.

Again, following a pattern in economic conversion that other manufacturing cities have experienced, Volta Redonda not only headed in the direction of a broader service economy, but also targeted the more specific medical-educational sector, similarly to Pittsburgh, Baltimore, albeit on a smaller scale. Indeed, as well as CSN and some retail companies, the top ten members of Volta Redonda's main business organization (ACIAP-VR) include three universities and one hospital. It is fair to say that in a trend common to other old industrial cities, Volta Redonda's shift towards a service economy has not made up for job losses in the manufacturing sector and has also resulted in a decrease in labor income.

Despite all the similarities between Volta Redonda and other manufacturing cities in terms of economic reconversion processes, it is worth underlining here a unique trait displayed by the Brazilian city. Here, the steel company is still the main local economic stakeholder. It has not lost its position as the principal individual employer, and it owns $36 \%$ of the city's land, as well as a property portfolio that includes clubs, schools, hospitals and farms. ${ }^{4}$ In addition, it accounts for $50 \%$ of the total property tax collected by the municipality. 
Table 2 - Main associated member companies (ACIAP-VR, 2016)

\begin{tabular}{c|l|l}
\hline & \multicolumn{1}{|c|}{ Company } & \multicolumn{1}{|c}{ Sector } \\
\hline 1 & CSN & Industry \\
2 & UnimedVR & Med/Hospital \\
3 & Royal Supermercados & Retail \\
4 & Floresta Supermercados & Retail \\
5 & Drogaria Moderna & Retail \\
6 & Drogaria Retiro & Retail \\
7 & UGB & Education/University \\
8 & UBM & Education/University \\
9 & UniFOA & Education/University \\
10 & Transporte Excelsior & Transportation \\
\hline
\end{tabular}

Source: ACIAP.

The lingering dependence of the city on the company's fate ${ }^{5}$ is a subject of concern at the local business association (ACIAP-VR), which in 1997 launched a movement called Vamos Repensar Volta Redonda ("Let's Rethink Volta Redonda") to figure out alternative economic directions for the city. As reported by the local magazine Revista Primeira Página: "ACIAP is going to promote its project Vamos Repensar Volta Redonda. It dreams of creating new economic hubs around universities, hardware and metal-mechanical companies. In the words of the association's vice-president, "we hope the movement will not amount to an isolated act on the part of ACIAP-VR. We hope that it evolves to be a collective action with a broad scope, capable of including representatives from the city hall, city council and judiciary; and businessmen, no matter the size of their companies, religious leaderships and neighborhood associations" (RPP, n. 33, 1997).

As it is widely known by local actors, Volta Redonda's recent history has unfolded in the opposite direction to that envisioned and urged by its main business association. Instead of evolving towards a pattern of consensual politics, it has become a stage for conflict and group polarization. Indeed, in the wake of company privatization, the city witnessed the proliferation of groups and the emergence of a polarized hyper pluralism that hindered, if not fully prevented, any process of coalition building. It has also witnessed a harsh standoff between CSN and local political actors in the last few years.

As Clarence Stone (1989) reminds us in his theory on regime politics, cities rely on a commitment between private and public 
actors that assemble the necessary resources to implement ("power to") different policy agendas. Consensus accommodation and coalition building therefore lie at the heart of urban and economic development. In this sense, Volta Redonda has undeniably failed to build institutional channels to bridge the gap between market and state actors as a step towards developmental policies. The local president of the engineers' union clearly exposes the astounding extent of this conflict and the lack of institutional bridges in the city: "The relationship between CSN and the city is bad. It is neither as clear nor as healthy as it was in the past. A relationship of trust was broken. Why? Because relations broke down between the company on one hand, and the mayor, the engineers' union, the construction union, the social movements and the church on the other. In addition, the company itself did not take part in the mayoral elections [...] we will only overcome our current situation when everybody comes together, including CSN and other companies" (Lima, 2010, p. 209).

Unlike Volta Redonda, Pittsburgh pursued its developmental path based on a social corporatist framework, which even if it was skewed in favor of elite politics, set up a culture of consensus and conflict accommodation. As Ferman (1996) underlines, Pittsburgh's renaissance in the 1940s was carried out within a strict corporatist institutional framework: "Economic development was carried out within a corporatist decision-making structure [...]. The shape of the new regime was almost immediately set with the establishment of the urban development authority (URA - 1946), the institution with primary responsibility for Pittsburgh's renaissance. By formally joining the public and private sectors, the URA provided the institutional base for the growth machine" (p. 49). In Pittsburgh, social corporatist structures and the consequent pattern of corporatist politics were so ingrained in both institutions and organizations that the ensuing steps of developmental policies, such as neighborhood incorporation, followed the corporatist logic. "The route to neighborhood incorporation [...] represented an extension of the logic of corporatism to the neighborhoods. Institutions were set up to give representation to peak associations, thus placing neighborhood issues in the sphere of elite politics" (Ferman, 1996, p. 109).

In summary, social corporatism in Pittsburgh paved the way for a pattern of consensual politics that opened up the possibility for coalition building and the pursuit of five decades of growth policies. It is worth mentioning that, although these coalitions brought policy together between state and market actors, with the later inclusion of neighborhoods, business actors organized and played a dominant role in Pittsburgh's urban regime. As Ferman (1996) highlights: "Pittsburgh's regime was formed explicitly for the purposes of economic development, with the major initiative coming from the most powerful member of the business community. As a result, economic elites dominated the regime. With economic objectives as the guide and economic elites at the helm, the regime steered much of its activity towards the civic-sector arena. Operating in an 
arena where the underlying logic is one of cooperation and civility the regime adopted a form of governance resembling the social production model as described by Stone [...] this cooperative orientation was reinforced by the regime's primary focus on large scale development projects that required substantial participation from public and private actors" (p. 137).

Almost in the opposite direction to Pittsburgh, state corporatism in Volta Redonda represented top-down, artificial and shortlived unity between local actors that was not by any means capable of setting up lasting relationships of trust and cooperation. When the state corporatist structure fell down, group fragmentation and a pattern of conflicting politics came to the surface. Unlike Pittsburgh, poorly organized local economic actors in Volta Redonda were not able to open up a path of growth. On the contrary, the aftermath of state corporatism meant the gap neither formed a bridge between the market and the state nor mitigated the standoff between CSN and local political actors. Analyzing the case of Volta Redonda, it can be argued that state corporatism not only fails to organize business, but is also unsuccessful in fostering enduring consensus and cooperation. In the same way, Schmitter's evaluation of the shortcomings of state corporatism can be easily extended to a subnational level. "Countries locked into state corporatism at an early state of development are likely to find it much more difficult to evolve toward such a consensual solution. There the established pattern is one of asymmetric dependence, inauthentic and fragmented representation, weak associational loyalties, suppressed or manipulated conflict, little mutual respect among groups, no effective means of appealing to wider publics and pervasive state bureaucratic control" (1974, pp. 126-127).

\section{Metropolitan Region of Rio de Janeiro: clientelism, distributive goods and the disincentive to growth politics}

Whereas state corporatism, as shown in the last section, amounts to an artificial pattern of cooperation among private and public actors that ultimately makes way for patterns of severe group conflict and weak bridges connecting the market and the state, political machines and clientelist institutions have been more effective in managing and offsetting conflict. It is widely known that the "efficient secret" of clientelism lies in its propensity to bring distributive politics to the forefront, to the detriment of regulatory and redistributive politics. In addition, political machines embedded in clientelism are successful in dealing with conflict to the extent that they set in motion simultaneous processes of fragmentation and aggregation of demands, which are vertically processed through the logic of individual favors. To a large extent, clientelism leads to a double process of group demobilization and accommodation.

For all that, some political machines have been described as capable of fostering developmental politics. According to Ferman's analysis, this was the case for Chicago's political 
machine, where Richard Daley managed to please voters and businessmen at the same time, pursuing a policy of simultaneous favor exchange and economic growth: "[...] the machine practiced a policy of the individual based on a material exchange of jobs for votes and on ethnic loyalties. Issues were avoided because they contained potential for division and for conflict. The abundant supply of discretionary resources allowed the machine to maintain a forced army of patronage workers and a sufficient cadre of voters. This means of securing the vote provided the machine with the discretion to practice an elitist style of policy politics. Typically, bankers, businessmen and labor leaders were the principal beneficiaries of the machine policy process, which was centered around major economic development projects" (1996, p. 32).

If Chicago's political machine, as described from the perspective of Ferman's analysis, seems not only not to prevent, but also to foster growth politics, this conclusion is completely at odds with the Brazilian literature on the institutional and economic implications of clientelism. Even where not overtly stated, academic analyses in Brazil share the view that clientelism severely hinders economic growth and that development policies require some other institutional framework, such as bureaucratic insularity or corporatism. ${ }^{6}$

In this section, a second case study at a local level is presented - the policy orientation of city council members in the municipalities of the Metropolitan Region of Rio de Janeiro, in which the institutional grammar of clientelism is so pervasive that political actors seem exclusively concerned about pursuing and providing distributive goods to their localities and constituents. In this case, and unlike Chicago, clientelism is clearly a hindrance to the pursuit of local development.

It must be said here that, compared to similar areas in other Brazilian states, the Metropolitan Region of Rio de Janeiro (MRRJ) displays an undeniably significant position: almost all of the municipalities ${ }^{7}$ in the region have socioeconomic characteristics that, from a structural perspective, provide them with both the "spending capacity" and the "administrative capacity" required for the implementation of substantial policies. Thus, it should be expected that, endowed with such structural assets, those municipalities behave as actors with autonomous capacity to formulate and implement growth policies.

Quite the contrary, the analysis both of the results of a survey carried out among 68 elected council members in seven municipalities of the MRRJ (described in detail in section below) and of the legislative output of the Rio de Janeiro and Japeri municipal assemblies indicates that local development and growth policies are far from being held as a priority by legislators:

- According to attitudinal data, a markedly parochial profile is detected among council members in the MRRJ. There is a clear priority given to distributive policies and an emphasis on casework activities of an assistentialist nature. Mandates that are sustained and renovated based on "social centers" 8 seem to represent an extreme form of specialization in this type of activity.

- Although city councils in the MRRJ are able to legislate on important areas of policy - such as land use, taxes, transport and urban development -, council members forego this 
possibility, limiting themselves to just providing "recommendations" 9 - following guidelines for distributive politics.

Summing up, from the survey results concerning both the perceptions and attitudes of city councilmen in several municipalities of MRRJ, it is possible to state, in agreement with previous research carried out on the national scale, that also at local level the grammar of clientelism amounts to an undeniable institutional barrier to local development. Distributive politics completely overshadows developmental concerns and strategies.

\section{Perception of the mandate and legislative activities of council members in the MRRJ}

During the year of 2014, 68 council members from the city councils of seven municipalities in the MRRJ - Mesquita, Duque de Caxias, Belford Roxo, São João de Meriti, Nilópolis, Nova Iguaçu and Niterói - were given a questionnaire in order to identify: a) the basis for the council members' mandates and their respective electoral connections; $b$ ) the vectors of their legislative activities, and c) to what extent their orientation was parochial in the exercise of their mandates.

It is important to reiterate here the context in which the inquiry into agenda power and into the policy orientation (parochialism or universalism) of the city councils was carried out. It should be emphasized that after the 1988 constitution, the powers of Brazil's city councils were increased considerably, above all in terms of urban land use regulation, which became the subject of law initiatives by local executive and legislative powers. Added to this were new powers for council members to legislate on municipal taxes and establish regulatory standards for transport, the environment, municipal postures and city zoning parameters on their own initiative.

From these institutional and structural indications, it should be expected that council members from the municipal assemblies of the MRRJ were engaged in the production of policy through the ordinary legislative process. However, attitudinal evidence gathered from the survey carried out among the council members suggests a radically different conclusion. As shown in Table 3, activities that are strictly of a legislative nature - draft laws and amendments - take second place. What the literature describes as casework - non-legislative activities - represents the fundamental activity of legislators in municipal assemblies in the MRRJ.

Significant indirect evidence of the disengagement of council members in developmental policies may be inferred from the degree of familiarity with specific policy areas. As Table 4 demonstrates, those areas for which council members can legislate in order to stimulate local development, namely urban policy and economic policy, are in fourth and last place, respectively, in a ranking of council members' familiarity. As important as the observation that these areas are relegated to the background is the identification that the main priority is attributed to actions under the generic heading of "social policy", which are possibly developed outside of legislative channels. 
Table 3 - Legislative and non-legislative activities developed along mandates of council members in the MRRJ

\begin{tabular}{l|c|c|c|c}
\multicolumn{1}{c|}{ Activity/frequency } & Frequently & Rarely & Never & Total \\
\hline Answering or leading on voters' claims & 98.5 & 1.5 & 0.0 & 100.0 \\
Dealing with bureaucracy for local leadership demands & 83.8 & 10.3 & 4.4 & 100.0 \\
Presenting draft laws & 72.1 & 22.1 & 5.9 & 100.0 \\
Amending draft laws & 27.9 & 51.5 & 20.6 & 100.0 \\
\hline
\end{tabular}

Source: Prepared based on data obtained from a survey carried out in 2014 by the author.

Table 4 - Degree of council members' familiarity according to area of policy

\begin{tabular}{|c|c|c|c|c|c|c|c|}
\hline $\begin{array}{c}\text { Area of Policy/ } \\
\text { Degree of } \\
\text { Knowledge }\end{array}$ & $\begin{array}{l}\text { Social } \\
\text { Policy }\end{array}$ & Construction & Education & $\begin{array}{l}\text { Urban } \\
\text { Policy }\end{array}$ & Health & Transport & $\begin{array}{c}\text { Economic } \\
\text { Policy }\end{array}$ \\
\hline High & 77.9 & 58.8 & 52.9 & 51.5 & 48.5 & 33.8 & 20.6 \\
\hline Reasonable & 16.2 & 32.4 & 42.6 & 44.1 & 42.6 & 52.9 & 69.1 \\
\hline Low & 4.4 & 7.4 & 2.9 & 2.9 & 7.4 & 10.3 & 8.8 \\
\hline Unknown/no response & 1.5 & 1.5 & 1.5 & 1.5 & 1.5 & 1.5 & 1.5 \\
\hline Total & 100,0 & 100,0 & 100,0 & 100,0 & 100,0 & 100,0 & 100,0 \\
\hline
\end{tabular}

Source: Prepared based on data obtained from a survey carried out in 2014 by the author.

Table 5 - Council members with social centers in the MRRJ

\begin{tabular}{c|c|c}
\hline & $\mathbf{n}$ & $\%$ \\
\hline Yes & 25 & 36.8 \\
No & 43 & 63.2 \\
\hline Total & 68 & 100,0 \\
\hline
\end{tabular}

Source: Prepared based on data obtained from a survey carried out in 2014 by the author. 
While some analysts suggest (Kushnir, 2010) that half of the council members elected in the capital of the state of Rio de Janeiro manage social centers, $37 \%$ of the council members in the assemblies studied confirm that they have at least one social center. This percentage suggests the centrality of casework in the area of social assistance, which is carried out by city councils outside of legislative channels or bureaucratic jurisdictions.

If the social center is the result of the extreme specialization of mandates based on service provision, and generally for segments located in deprived areas, two features should be highlighted that mean this type of service provision is different from what the North American literature describes as casework. On the one hand, council members in the MRRJ seem to offer a range of services directly to their respective clientele without the involvement of bureaucracy; on the other hand, these services seem to amount exclusively to individual, disaggregated social benefits.

Questioned on the activities they prioritize in their contact with their electoral bases, the council members surveyed indicated that direct contact with voters and provision of social services were most important to them, as shown in Table $6 .{ }^{10}$ Adding this information to the council members' declared familiarity with the area of social policy (an area that attracts more attention than urban or economic policy) and to the percentage of council members that claim to manage social centers, the assistentialist orientation of their mandates is clear. Local economic development is certainly not a priority for political actors.

Table 6 - Activities prioritized by council members in contact with their electoral bases

\begin{tabular}{l|c|c}
\multicolumn{1}{c|}{ Activity } & Order & Mean \\
\hline Direct contact with voters through meetings & $1^{\text {st }}$ & 8.63 \\
Provision of social services & $2^{\text {nd }}$ & 8.25 \\
Meetings with local leaders & $3^{\text {rd }}$ & 7.75 \\
Media appearances & $4^{\text {th }}$ & 5.75 \\
Meeting voters' requests & $5^{\text {th }}$ & 5.43 \\
\hline
\end{tabular}

Source: Prepared based on data obtained from a survey carried out in 2014 by the author. 
Legislative activity in two municipalities in the MRRJ: Rio de Janeiro and Japeri

Evidence on the legislative mandates of two municipal assemblies in the MRRJ - Rio de Janeiro and Japeri - was evaluated. Whereas these municipalities may have opposing positions for a series of indicators ${ }^{11}$ such as HDI, GDP per capita, population and location within the MRRJ, they converge in one aspect: despite being able - from an institutional and socio-structural perspective - to host assemblies that can play a proactive role in the field of local development through legislative action, in both cases this potential is not used. In the municipal assemblies in Rio de Janeiro and Japeri, council members sideline the legislative function in general, especially legislation aimed at local economic development.

From a survey and classification on the usual legislative production of the Municipal
Assembly of Rio de Janeiro along the 20012004 legislature, D'Avila Filho et al. (2011) verified that of all of the presented proposals, $57 \%$ corresponded to motions, $29 \%$ to recommendations and only $4 \%$ to draft laws. A similar pattern of legal initiatives having a minor role in legislative production was observed for the first three years (2009/2010/2011) in the city council of Japeri. As shown in Table 7, the draft laws presented occupy a lower position. Recommendations, however, are the proposals given the highest importance in both assemblies.

Whereas attitudinal data suggest that council members in the MRRJ prioritize casework activities - or the provision of disaggregated social benefits outside the legislative jurisdiction -, behavioral evidence reveals a second factor that guides council members' behavior: the allocation of particularized benefits to specific groups and targeted regions goes hand in hand with the claim of personal credit for the actions that are implemented.

Table 7 - Proposals presented in the Municipal Assembly of Japeri (2009-2011)

\begin{tabular}{l|c|c}
\hline \multicolumn{1}{c|}{ Proposal } & Total & Percentage (\%) \\
\hline Recommendations & 164 & 49.54 \\
Legislative decrees & 95 & 28.7 \\
Motions & 34 & 10.27 \\
Draft laws & 32 & 9.66 \\
Approved laws & 6 & 1.81 \\
Expert opinions & 0 & 0 \\
Requirements & 0 & 0 \\
\hline
\end{tabular}

Source: Municipal Assembly of Japeri. 
In order to understand the congruence between the legislative "recommendations" and this factor, it is worth remembering a classic passage by Mayhew (1974) on one of the central dimensions of legislative activity from a distributive politics' perspective:

"[...] a second activity may be called credit claiming, defined here as acting so as to generate a belief in a relevant political actor (or actors) that one is personally responsible for causing the government, or some unit thereof, to do something that the actor (or actors) considers desirable". (pp. 52-53)

"Particularized governmental benefits, as the term will be used here, have two properties:

(1) each benefit is given out to a specific individual, group or geographical constituency, the recipient unit being of a scale that allows a single congressman to be recognized [...] as the claimant for the benefit; (2) each benefit is given out in apparently ad hoc fashion, with a congressman apparently having a hand in the allocation". (Mayhew, 1974, p. 54)

Therefore, recommendations in form and in material terms involve, without any doubt, an instrument of credit claiming by council members through the allocation of particularized benefits via the executive power and its agencies. How do the mechanics of this work? The council member recommends to the mayor the need for a particular intervention - usually related to paving, sanitation or street illumination. The authorship and small scale of the demand are characteristic of all recommendations, making these a suitable instrument for actions with a distributive purpose. The thematic areas of recommendations in the Municipal Assembly of Japeri are listed in Table 8.

Table 8 - "Recommendations" by council members of the Municipal Assembly of Japeri to the executive power - 2009-2011

\begin{tabular}{l|c|c}
\hline Public roads & 90 & $38 \%$ \\
Basic sanitation & 72 & $30 \%$ \\
Public lighting & 33 & $14 \%$ \\
Public education & 28 & $12 \%$ \\
Governmental action & 28 & $12 \%$ \\
Sport/Leisure & 26 & $11 \%$ \\
Public health & 25 & $10 \%$ \\
Public events & 11 & $5 \%$ \\
Tree planting & 10 & $4 \%$ \\
Public cleaning & 10 & $4 \%$ \\
\hline Total & 239 & $100 \%$ \\
\hline
\end{tabular}

Source: Municipal Assembly of Japeri. 
Therefore, both the attitudinal and behavioral evidence suggests that local political actors in the municipalities located in the Metropolitan Region of Rio de Janeiro are guided by the grammar of clientelism, prioritizing the distribution of disaggregated benefits for their respective clientele.

\section{Conclusion}

It is widely recognized that economic actors play an important role in shaping the fate of US cities. During a period that can be identified as the first phase of urban studies in the US, researchers tried to figure out and measure the extent to which business determined state policies. As Hanson and his colleagues (2010) argue, "the debate that has been waged since the seminal works of Hunter (1953), Dahl (1961) and Polsby (1963) has been whether the role of business is determinative or whether business is merely one of many groups exercising influence in a pluralist polity" (p. 1). While proposing a new concept of power, which no longer enquires into who is in control but aims at identifying who has the capacity to act and to accomplish goals, Clarence Stone (1989) launched a second phase of research into cities and coined his theory or concept on urban regimes, heavily influenced by both neo-pluralism and political economy scholarship. Stone claims that as a result of the necessary compromise between economic and state actors, regimes are built upon resources that are informally assembled by means of coalition building processes on one hand, and with a view to implementing a specific policy agenda on the other. While urban regime theory pays tribute to pluralism when it sets politics (coalition process) at the core of regime formation, at the same time it relies on the political economy approach to cities, acknowledging that economic actors always enjoy a privileged position among coalition partners. In the words of Ferman (1996), "the concept of an urban regime captures this bridging process. By bringing together economic and political elites, a regime constitutes the informal arrangements by which public bodies and private interests function together in order to be able to make and carry out government decisions. Since cooperation is fundamental to this relationship, the question of 'who cooperates and how their cooperation is achieved' is central to the understanding of how a city is governed and its overall policy orientation" (p. 2).

As mentioned above, in the last few decades factors relating to globalization, such as state rescaling and state reform, have brought the governance of cities and city regions to the surface, both as a normative concern and a research subject. In order to meet the challenge of understanding the new dynamics of city and regional governance, researchers in Europe and Latin America have been resorting to theories that emerged during the second wave of urban studies in the US, mainly urban regime and growth machine theories. It is worth noting here that, while trying to evaluate the fit and adequacy of these theories to realities found outside cities in the US, most authors seem to ask the wrong comparative question, as they compare cities and assume a homogeneous landscape of city governance and state/market relations in all 
countries under analysis, due to the unifying force of their nation states. Even conceding that globalization has brought about new territorial scales, causing the fragmentation of otherwise homogeneous spaces, their assumptions seem to include a monolithic nation state that conditions subnational realities in the same direction. Even when not overtly assumed, the nation state bias is undeniably present in their evaluation, as can be identified in Harding's remarks: "The evidence presented in this article suggests that three key observations that can be made about the use of urban regime and growth machine approaches in Britain [...] it is difficult, if by no means impossible, to apply some of their insight cross-nationally [...] many of the attempts to apply the insights of urban regime theory and the growth coalition thesis within a British context has been insufficiently rigorous" (1999, p. 689). In both its semantics and its content, Harding's assumption is a homogenous nation state at the root of a political economy, evenly distributed at a local level.

Therefore, it should be stressed that this study involves quite a different assumption from Harding's, as it represents an attempt to seriously bring back cities' and city regions' political economies in Brazil. Therefore, it agrees with Locke's perspective (1995), according to which a national political economy should not be viewed as a coherent national system, but rather as a somewhat incoherent composite of diverse subnational patterns that coexist (often uneasily) within the same national territory (p. 174). It goes without saying that if we are to assume the diversity of local political economies, we have to suppose that the use and results of US urban theories will vary cross-regionally rather than cross-nationally. It should be expected that insights from urban regime theory apply unevenly to cities and city regions within the same national territory.

In this essay, attention is brought to the different institutional frameworks or grammars that are mingled together in Brazil's nation state and that are to be found in their more disaggregated and purer form moving towards the subnational level of cities and city regions: clientelism, corporatism, bureaucratic insularity and universalism of procedures. Each institutional grammar is expected not only to cause a different pattern of relations between the state and society, but also to impact with different signs and strengths on market dynamics, the organization of business and activism at a local level. It is worth remembering that, although urban regime theory relies on the neo-pluralist assumption that liberal democracies, markets and states lead to a double and interdependent system of authority where business decisions are critical to public welfare, institutional grammars that foster business activism are more prone to create local political economies that can be interpreted from the urban regime perspective. It has been demonstrated in two case studies the city of Volta Redonda and the Metropolitan Region of Rio de Janeiro - that corporatism and clientelism at a local level in Brazil are far from being able to foster political economies with a kind of civic cooperation between economic and political actors, as envisaged by urban regime theory. Indeed, state corporatism in the steel city of Volta Redonda has achieved an artificial and short-lived unity between business and state that sparked into myriad conflicting groups as the corporatist façade began to 
fade away. Clientelism in the Metropolitan Region of Rio de Janeiro signified the primacy of distributive politics over redistributive or developmental politics, and indirect evidence has shown a pattern of business cooptation and rent-seeking activities. That said, it must be stressed that two of the institutional grammars underpinning the Brazilian state clearly determine a non-cooperative pattern of relations between the market and state actors, making it difficult - if not impossible - for these local political economies to be explained through insights from urban regime analysis.
As an inaugural investigation, it is more important to identify some research questions that lie ahead than arriving at any final conclusions. It is worth testing: a) how the four different institutional grammars are distributed throughout the Brazilian municipalities; b) whether clientelism and machine politics can also foster growth politics, as was the case in Chicago; and c) whether the universalism of procedures at a local level leads to market relations and patterns of civic cooperation between the market and state actors, this being the basis of urban regime politics.

\section{Nelson Rojas de Carvalho}

Universidade Federal Rural do Rio de Janeiro, Instituto Multidisciplinar, Departamento de História. Seropédica, RJ/Brazil.

nrojascarvalho@gmail.com

\section{Notes}

$(*)$ This is a revised version of a paper prepared for presentation at the 2016 meeting of the American Political Science Association, Philadelphia, september, during my postdoctoral stage under the generous supervision of Clarence Stone. It was supported by a Capes fellowship

(1) On the decentralization process in Brazil during the 1980s, see Celina Souza (1997).

(2) Along with the state-owned oil company Petrobras and the mining company Companhia Vale do Rio Doce (CVRD), CSN was designed to play a central role in Vargas' project for development.

(3) The company's headquarters occupied a 16-story building that remains closed to date. The relocation to São Paulo is the most expressive symbol of a new process that was unleashed in the city: the detachment of the company from its territory.

(4) Despite fierce popular opposition, all of these assets were privatized along with the company.

(5) Since its privatization, CSN has expanded outside the city and merged with economic groups, such as the Vicunha Group. 
(6) Whereas it is beyond the scope of this study to evaluate when and for what reasons political machines and economic growth do not get along, it is worth pointing out a trait of Brazilian federalism that may have a stake in the outcome of this. As Arretche (2012) notes, on average $70 \%$ of the budgets for Brazilian municipalities are constitutionally earmarked for social areas such as education, housing, sanitation, social services and social security.

(7) There are seventeen municipalities within its legal boundaries: Rio de Janeiro, Belford Roxo, Duque de Caxias, Guapimirim, Itaboraí, Japeri, Magé, Nilópolis, Niterói, Nova Iguaçu, Paracambi, Queimados, São Gonçalo, São João de Meriti, Seropédica, Mesquita and Tanguá. Most of these (65\%) have a population over 100,000 and an average (88\%) or high (2\%) score on the Human Development Index (HDI).

(8) Social centers are organizations maintained by council members to provide a range of services for voters, from professional training and qualification to medical attention.

(9) "Recommendations" are legislative instruments through which council members indicate to the mayor the need for specific interventions in the neighborhoods of their municipalities.

(10) In order to know the political resources most valued by council members when working in their constituencies, we asked them to assign a value to five different activities. The values range from 1 - least important - to 10 - most important - and are displayed in Table 6.

(11) The municipality of Japeri has a population of 100,000 , the lowest HDI in the MRRJ - although this is an average value (0.724) - and a GDP per capita of $\mathrm{R} \$ 3,972.33$. Rio de Janeiro, however, has a population of $6,182,710$, the second highest HDI in the MRRJ (0.842) and a GDP per capita six times higher than that of Japeri: $\mathrm{R} \$ 19,243.95$.

\section{References}

ARRETCHE, M (2012). Democracia, federalismo e centralização no Brasil. Rio de Janeiro, Editora FGV.

BRENNER, N. (2004). New State spaces: urban governance and the rescaling of statehood. Oxford, Oxford University Press.

DAHL, R. (1961). Who Governs? Democracy and power in an American City. New Haven, Yale University Press.

D'ÁVILA FILHO, P. M. et al. (2011). Produção legislativa e intermediação de interesses: uma análise das Indicações na Câmara Municipal do Rio de Janeiro. Mimeo.

DULCI, J. A. (2008). Reestruturação Produtiva e Mercado de Trabalho no Vale do Paraíba Fluminense: Região Ganhadora ou Perdedora? Dissertação de Mestrado. Rio de Janeiro, Instituto Brasileiro de Geografia e Estatística.

ESTEVEZ, A. (2012). "Do Fordismo ao neoliberalismo: transformações do mundo do trabalho em uma cidade siderúrgica brasileira". In: MACERI, S. (org.). Temas de economía político-social. Buenos Aires, Ediciones Cooperativas, pp. 173-210.

FERMAN, B. (1996). Challenging the growth machine: neighborhood politics in Chicago and Pittsburgh. Lawrence, University Press of Kansas. 
FITZGERALD, F. (1988). "Pittsburgh, Pennsylvania: from steel town to advanced technology center" In: BINGHAM. R. and EBERTS, R. (eds.). Economic restructuring of the American Midwest. Boston, Kluwer academic publishers.

HANSON, R. et al. (2010). Corporate citizenship and urban problem solving: the changing civic role of business leaders in American cities. Journal of Urban Affairs, v. 23, i. 1, pp. 1-23.

HARDING, A. (1999). Review Article: north urban political economy, urban theory and British research. British Journal of Political Science, n. 29, pp. 673-698.

HUNTER, F. (1953). Community power structure: a study of decision-makers. Chaptol Hill, The University of South Carolina Press.

KUSCHNIR, K. (2010). Clientelismo revisitado. O Globo. Rio de Janeiro, p. 33.

LIMA, R. da C. (2010). A "Reinvenção" de uma Cidade Industrial: Volta Redonda e o pós-privatização da Companhia Siderúrgica Nacional. Tese de Doutorado. Rio de Janeiro, Universidade Federal do Rio de Janeiro.

LOCKE, R. (1995). Remaking the Italian Economy. New York, Cornell University.

LOWI, T. J. (1972). Four systems of policy, politics and choice. Public Administration Review, v. 32, n. 4, pp. 298-310.

MAYHEW, D. (1974). Congress - the electoral connection. New Haven, CT, Yale University Press.

MOLOTOCH, H. (1976). The city as growth machine: toward a political economy of place. American Journal of Sociology, v. 82, n. 2, pp. 309-332.

NUNES, E. (1997). A gramática política do Brasil: clientelismo e insulamento burocrático. Rio de Janeiro, Zahar.

PETERSON, P. (1981). City Limits. Chicago, University of Chicago Press.

POLSBY, N. (1963). Community Power \& Political Theory. New Haven, Yale University

RHODES, R.A.W. (1997). Understanding governance: policy networks, governance, reflexivity and accountability. Philadelphia, US, Open University Press.

SCHMITTER, P. (1974). Still the Century of Corporatism? Review of Politics, n. 36, pp. 85-131.

SCHNEIDER, B. R. (2004). Business Politics and the State in Twentieth-Century Latin America. Cambridge, Cambridge University Press.

SOUZA, C. (1997). Constitutional engineering in Brazil: the politics of federalism and decentralization. London/New York, Macmillan/St. Martin's press.

STONE, C. (1989). Regime politics: governing Atlanta 1946-1988. Kansas.

TAYLOR, P. (1995). "World Cities and Territorial States: the rise and fall of their mutuality". In: TAYLOR, P. and KNOX, P. World cities in a world system. Cambridge, Cambridge University Press.

Texto recebido em 2/nov/2016

Texto aprovado em 17/maio/2017 